\title{
Hjerteinfarkt i ødemarken i Peru
}

\author{
I april 2014 ble jeg rammet av hjerteinfarkt under en fottur i Peru. Evakueringen og sykdomsforløpet \\ ble dramatisk.
}

Høsten 2013 hadde jeg gjennomgått et hjerteinfarkt, som ble raskt behandlet med utblokking og stenter. Jeg hadde tidligere stort sett vært frisk, men 65 år gammel måtte jeg plutselig forholde meg til egen sykdom.

Etter infarktet bedret den fysiske tilstanden seg raskt med jevn trening, og etter 4-5 måneder var det fysiske nivået omtrent som før infarktet, slik at hjertet kunne belastes opp mot maksimal pulsfrekvens.

Min familie og jeg har alltid satt pris på å reise, se nye steder og møte nye utfordringer. Senhøsten 2013 diskuterte vi ønskede reisemål som kunne være mulig å gjennomføre i denne nye livssituasjonen. Koronar hjertesykdom er jo en kronisk progredierende sykdom, og vi så det som viktig å prioritere det vi ville ha gjort i livet før den fysiske kapasiteten ble redusert. Min kone og jeg kom frem til at vi begge ønsket å gå Inkastien (The Inca Trail) til Machu Picchu i Peru. Utfordringen ville bli den fysiske anstrengelsen i relativt stor høyde. Etter diskusjon med kyndige kolleger ble det vurdert at opphold i opptil ca. 4000 moh. var forsvarlig. Reisen ble bestilt, og avreise med reiseselskap fant sted knapt sju måneder etter infarktet.

\section{Akklimatisering og høydetilpassing}

Som anestesilege skjønte jeg at det var viktig å bruke tid på akklimatisering til høyden. Vi fulgte rådene i Morten Rostrups artikkel i Tidsskriftet: Unngå alkohol, spis lett, pass på hydrering og unngå anstrengelser (1). Det første møtet med høyden utløste heller ingen brystsmerter, som jo var den største bekymringen. Men den mest krevende fysiske utfordringen ville bli fot- turen der høyde og fysisk anstrengelse skulle kombineres.

Etter tre døgn på drøyt 3800 moh. ved Titicacasjøen gikk turen med buss til inkahovedstaden Cusco som ligger på 3300 moh. Underveis stoppet vi på et pass på 4300 moh. Heller ikke i denne høyden var det tegn til angina ved alminnelig gange. I Cusco fortsatte «testingen» med bakkegåing i stedet for museer og markeder. Det var ingenting som tydet på at en restenosering var på gang. Så etter en ukes uproblematisk akklimatisering var det klart for utfordringen.

\section{Inkastien}

Drømmeturen startet $\mathrm{i}$ «lave» høyder rundt $2600 \mathrm{moh}$. Det gikk lett og ledig. Planen var klar for oppstigningen dag 2: Tempo inverst til høyden, full stopp og rolig nedstigning

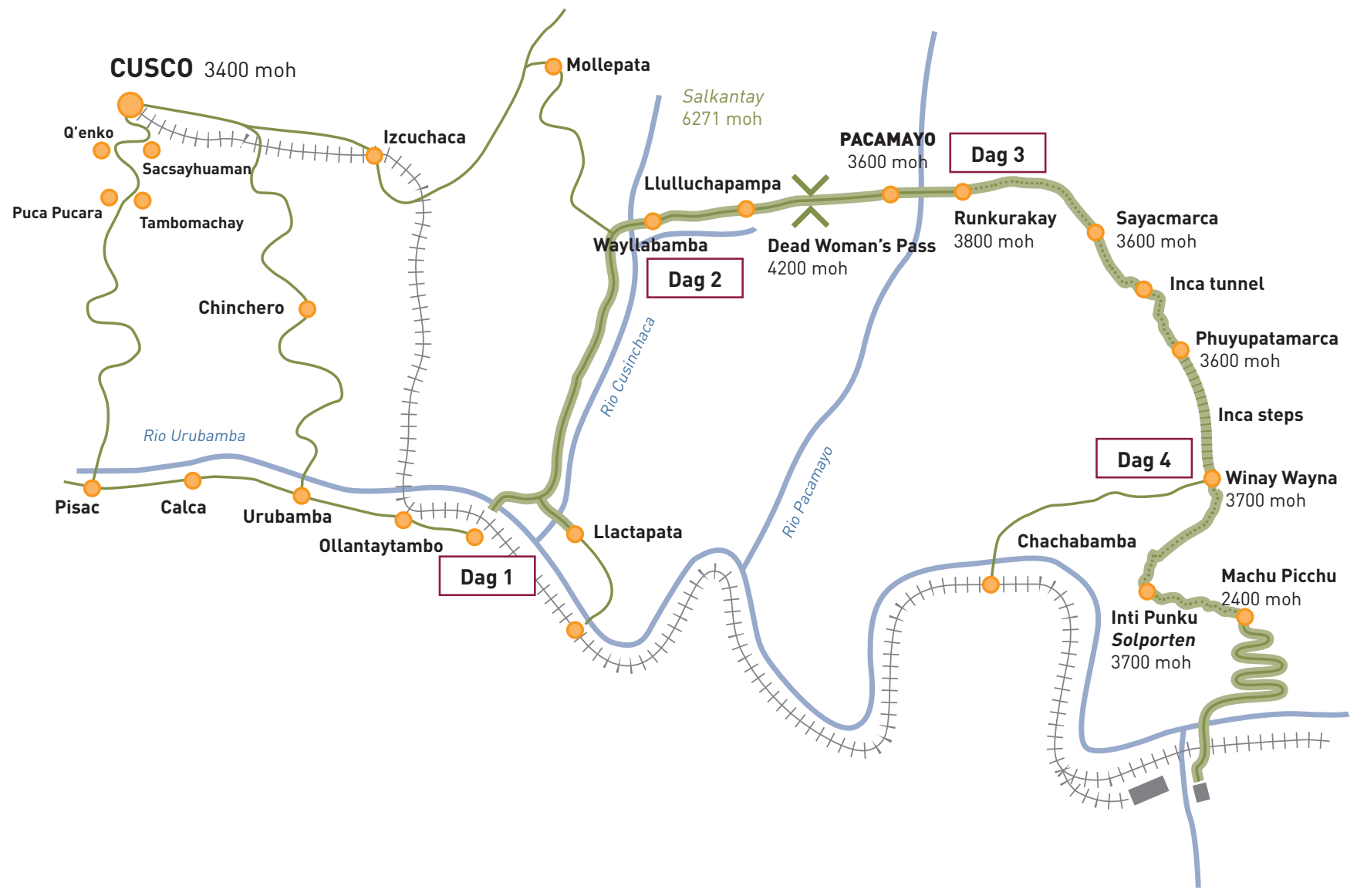




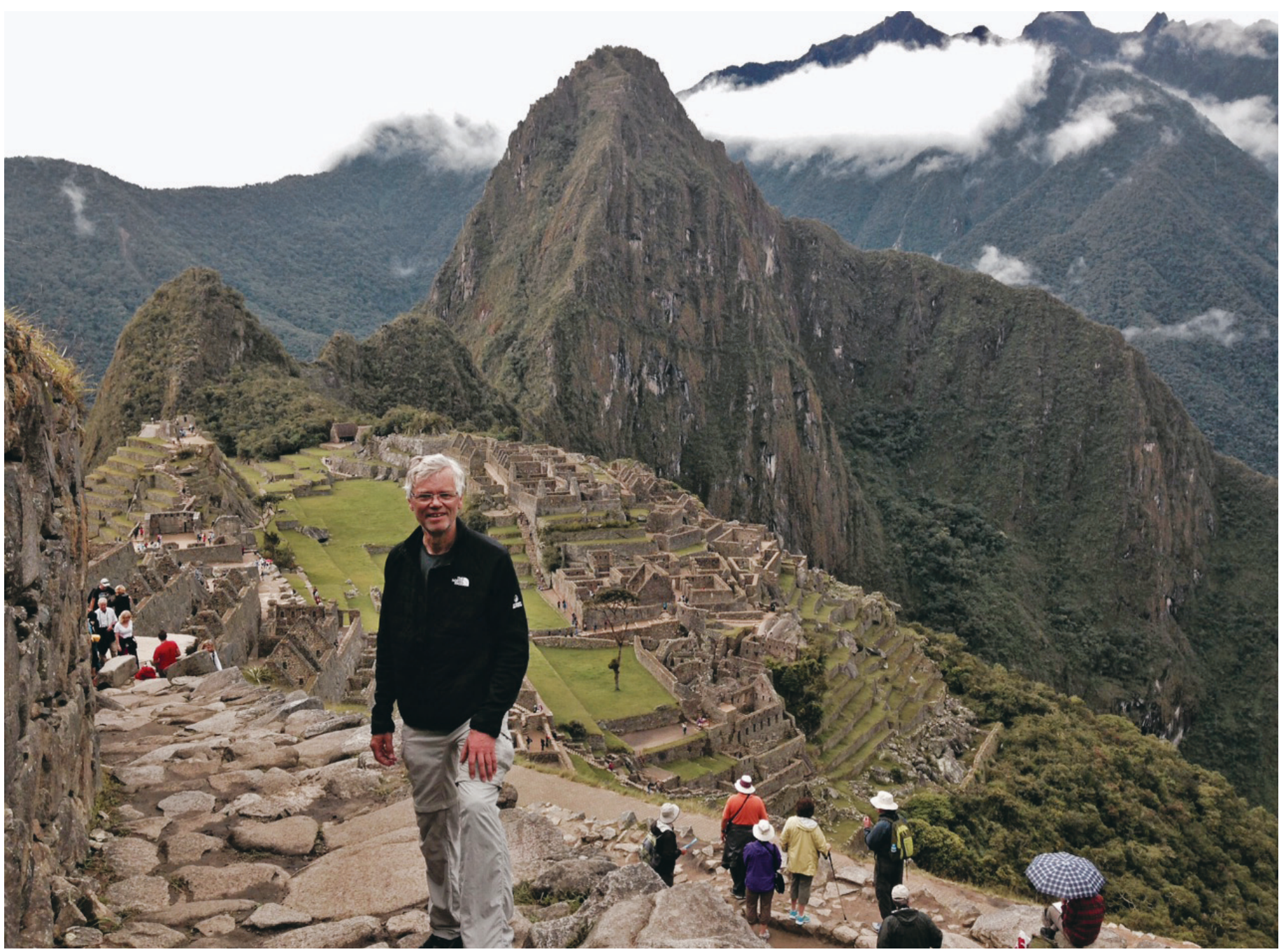

Ved Machu Picchu. Foto: privat

ved eventuelle brystsmerter. Nitroglyserinen var på plass i lommen, og væskeinntak ble viet stor oppmerksomhet. Svært forsiktig kom vi oss over Dead Woman's Pass på 4200 moh. Derfra gikk det lett ned til leiren i Pacamayo på 3600 moh.

Vel tre timer senere, i ro under lunsjen på ettermiddagen, fikk jeg moderate brystsmerter og følte meg uvel. Nitroglyserinen ga litt lindring. I samråd med en argentinsk kardiolog $\mathrm{i}$ gruppen vår ble det organisert evakuering neste morgen. Det kom to smerteanfall i løpet av natten, som i noen grad ble kupert av nitroglyserin. I et telt langt utenfor allfarvei med ustabil angina var jeg ikke høy i hatten, men merkelig nok ikke redd - mer trist ved tanken på at det kunne ende her, at alt jeg så frem til i livet fremover kunne bli tatt fra meg.

\section{Evakuering og sykehusopphold}

Evakueringen neste morgen var enkel. To innfødte bærere, ikke større enn meg selv, bar meg på ryggen på skift $20 \mathrm{~km}$ langs Inkastien. En av reisefølgets engelsktalende guider ble også med på denne turen. Bærerne brukte et «tørkle» av en lett presenning og knyttet meg til ryggen slik kvinner bærer barn i Afrika. De bar meg opp og ned bratte partier i til dels øsende regnvær. Distansen som er to dagsmarsjer for turistene ble tilbakelagt på 6-7 timer. Jeg så dem knapt spise, men delte min niste med nøtter med dem. En åpenbar energikilde for dem var tygging av kokablader. Jeg gikk litt innimellom på flater og de aller trangeste og bratteste partiene. Brukte 8-10 nitroglyserintabletter underveis. Det var slitsomt å bli båret, så det var godt da bærerne tok pauser. Blodtrykket ble målt underveis, det var foruroligende høyt: 190/100. Turen endte i Machu Picchu som åpenbarte seg i skoddeheimen ved Solporten. På dette tidspunktet følte jeg meg veldig kjekk.

Jeg tar av meg hatten for redningsmennene. Bare de som har gått Inkastien kan forstå hvilken prestasjon det var å frakte meg disse $20 \mathrm{~km}$ !
Fra Machu Picchu gikk turen i buss i 30 minutter til en lokal spansktalende lege. Den engelsktalende guiden viste nå sin berettigelse. Legen tok kontakt med et privat hjertesenter i Cusco og han fulgte meg på en halvannen times tur med et skranglete tog til Ollantaytambo der ambulanse med en kompetent engelsktalende kardiolog ventet. Blodtrykket var da tilfredsstillende: 140/90. Det var en stor lettelse. På hospitalet gjorde de en utmerket jobb, legen satte i gang tiltak etter boken.

Men noen detaljer sviktet. Det kunne skjedd mange steder. «Djevelen er i detaljene», som amerikanerne sier. På morgenen var jeg helt fin etter en god natts søvn. Troponinnivået var så vidt over det normale, og alt så lovende ut. Men så fikk jeg skikkelig vondt $\mathrm{i}$ brystet og oppdaget at nitroglyserininfusjonen var stoppet opp. Jeg kalte på hjelp umiddelbart. Det tok for meg uendelig lang tid før det dukket opp personell som hang opp en ny pose. De tok også bort surstoffet mens de tok EKG og glemte å sette det på igjen. 
Jeg merket at noe var galt da jeg igjen fikk vondt og skjønte at nå utviklet det seg et infarkt. Jeg dormet av 3-4 ganger, og ble hver gang vekket av alarmen på monitoren som hadde alarmgrense på 45 , og observerte selv frekvens ned mot 35 . I ettertid lurer jeg på om ikke jeg besvimte hver gang dette skjedde. Å si hvor langt pulsen hadde gått ned om jeg ikke hadde blitt vekket av alarmen, vet jeg ikke. Bradykardien og medfølgende hypotensjon skyldtes trolig Bezold-Jarisch-refleksen (2), vanligvis forbundet med nedre- eller bakreveggsinfarkt, slik forsikringsselskapets kardiolog vurderte det $i$ ettertid.

Grunnet brystsmertene ba jeg nå om morfin, synes også det tok lang tid i min hjelpeløshet. Det gikk fra vondt til verre: Jeg fikk voldsomme frysninger, temperaturen raste opp til $40{ }^{\circ} \mathrm{C}$ og jeg tenkte at dette tåler ikke et nyinfarsert hjerte, nå er det slutt. Rundt meg merket jeg angsten blant personalet. Jeg følte at det var en kamp for livet. Akkurat da var ikke legen til stede, så jeg tenkte som om jeg var behandlende lege og fikk personalet til å øke infusjon av nitroglyserin, gi surstoffet på tett maske med reservoar og mer smertestillende. Etter hvert gikk frysningene over, og brystsmertene klinget av. Jeg vet fortsatt ikke hva som var bakgrunnen for den «septiske» temperaturstigningen.

Det ble organisert evakuering med ambulansefly til hjertesenter i Lima. Den turen ble også dramatisk. Nå var det ingen som forsto engelsk. Hver gang transportmidlet ble skiftet, ble surstoff koblet fra i unødig lange perioder, slik jeg opplevde det. Dette var ille for meg som så altfor godt visste hva som sto på spill. Forsøk på å påskynde ble møtt med «tranquilo», og det virket som om jeg måtte slåss for morfin hele tiden. Bedre ble det ikke da jeg også fikk dyspné, om enn moderat. Jeg hadde ingen anelse verken om hjertefrekvens, blodtrykk eller annen behandling på denne turen.
Endelig fremme ved hjertesenteret i Lima var jeg pjusk med blodtrykk på 90/60. Vakthavende intensivlege ga meg diagnosen kardiogent sjokk. Det burde skremt livet av meg, men jeg mente jeg var klar i toppen og etter egen oppfatning verken kaldsvettende eller cyanotisk. Det ble gitt både noradrenalin og dobutamin. Heldigvis tok de meg raskt inn på angiografilaboratoriet, og to døgn etter at brystsmertene startet, ble det gjort angioplastikk på en tett stent. Etter det gikk det stort sett bra.

Min kone ankom Lima neste dag og fikk besøke meg på intensivavdelingen der jeg ble i tre dager. Det var en stor trøst ikke å være alene lenger.

Fra intensivavdelingen gikk det opp til sengepost, stort luksusenerom med «forværelse» og jacuzzibadekar. Pleien var utmerket, og kommunikasjonen med personalet gikk rimelig greit med iPadens språkprogram. I det hele tatt var tilgang til internett en vesentlig trivselsfaktor: slekt, venner og arbeidskamerater der hjemme var innen rekkevidde.

Etter hvert ble alle kanyler fjernet, bare blåmerker, hematomer og flebitter gjensto. Troponinnivået var da normalisert. Ekko viste normal venstre ventrikkel-funksjon med $60 \%$ ejeksjonsfraksjon.

\section{En dristig reise?}

Erfaringene med Perus helsevesen var stort sett gode. De farligste hendelsene fant sted etter at jeg var kommet under kyndig medisinsk behandling. Hadde nedreveggsinfarktet med Bezold-Jarisch-refleksen og septisk temperaturstigning kommet tidligere, hadde dette neppe gått bra. Detaljene som sviktet og som jeg opplevde som farlige for meg, kunne nok ha skjedd hvor som helst, selv om evakueringen fra Cusco til Lima ga grunn til engstelse, ikke minst fordi kommunikasjonen var umulig.

Mine venner vil neppe beskrive meg som en eventyrer, men noen synes nok det var en dristig reise. Tidspunktet var imidlertid valgt med omhu. Både min kone og jeg var klar over at turen kunne medføre risiko, selv om alt tydet på at stentene var patente, at jeg gikk på dobbel platehemming og at jeg var i god fysisk form. Det ville ha vært uforsvarlig å gå en slik tur uten å være en del av et reiseselskap, og det var en lykke at det var en kardiolog i følget. Jeg tålte høyden godt, likeledes økende fysisk aktivitet $i$ takt med akklimatiseringen. Jeg var forberedt på angina, som kunne mestres med nedstigning fra høyden, men ikke på infarkt. I ettertid er det lettere å se at jeg burde ha tenkt mer på risikoen ved potensiell evakuering fra uveisomme områder, mulighetene for helikoptertransport og problemene med et fremmed språk.

Takk til Olav Sellevold og John-Arne Skolbekken som oppfordret meg til å skrive og som har gitt verdifulle innspill til manus.

Ola Dale

ola.dale@ntnu.no

Ola Dale (f. 1948) er spesialist i anestesiologi og i klinisk farmakologi, professor ved Norges teknisk-naturvitenskapelige universitet og leder av Tidsskriftets redaksjonskomité.

\section{Litteratur}

1. Rostrup M. Reiser til de store høyder - akutt høydesyke. Tidsskr Nor Lægeforen 2002; 122: 1692-4.

2. Campagna JA, Carter C. Clinical relevance of the Bezold-Jarisch reflex. Anesthesiology 2003; 98 : $1250-60$.

Mottatt 13.1. 2015, første revisjon innsendt 12.3. 2015, godkjent 26.3. 2015. Redaktør: Erlend Hem. 